\title{
O papel da variável sexo/gênero na variação linguística em Piracicaba-SP
}

\author{
Rafaela Morelli* \\ Orientadora: Livia Oushiro
}

\begin{abstract}
Resumo
Conhecida principalmente pela realização de róticos, a variedade linguística no município de Piracicaba-SP ainda é relativamente pouco estudada. Busca-se investigar se há correlação entre o uso variável de róticos e o sexo/gênero do falante nessa comunidade de fala, e analisar quais outras variáveis influenciam a variação linguística, com foco na pronúncia de /r/ em posição de coda silábica, /r/ em posição de ataque silábico intervocálico e o rotacismo.
\end{abstract}

\section{Palavras-chave: \\ Variação linguística, dialeto caipira, variável sexo/gênero}

\section{Introdução}

Um os padrões notáveis que tem sido verificado em estudos sociolinguísticos e que é o foco desse projeto, é a tendência dos falantes do sexo feminino a favorecerem as formas consideradas "padrão" ou "de prestígio" nas respectivas comunidades (LABOV, 1990; PAIVA, 2004). Quanto às variáveis sociolinguísticas, esta pesquisa examina a pronúncia de $/ \mathrm{r} /$ em posição de coda silábica (p.ex., porta), /r/ em posição de ataque silábico intervocálico (p. ex. banheiro) e o rotacismo (p.ex., pranta e árbum).

As hipóteses iniciais que fomentam essa pesquisa são: (i) que a variante com maior grau de retroflexão em ataque e em coda silábica, bem como o rotacismo, são mais estigmatizados; e que, sendo assim, (ii) as informantes mulheres tenderão a utilizar uma variante menos retroflexa, apagamento ou, até mesmo, o tepe, em posição de ataque intervocálico e em coda silábica.

\section{Resultados e Discussão}

Os dados foram coletados por meio de entrevistas sociolinguísticas com 12 piracicabanos, sendo a amostra previamente estratificada de acordo com (i) seu sexo/gênero (masculino/feminino), (ii) sua faixa etária (18 a 34 anos, 35 a 59 anos, 60 anos ou mais) e (iii) o bairro onde o falante nasceu e mora (bairros mais ou menos afluentes). Os dados foram, então, analisados com o auxílio da plataforma R (R CORE TEAM, 2019) por meio de testes qui-quadrado.

As variáveis analisadas foram: ocorrência ou não ocorrência de rotacismo, $/ \mathrm{r} / \mathrm{em}$ ataque realizado como tepe ou retroflexo, apagamento versus realização e retroflexo forte versus retroflexo fraco para r em coda.

As variáveis sociais com associação significativa com as três variáveis dependentes foram: Informante, Sexo/gênero, Faixa Etária, Renda Familiar, Bairro de Origem e de Residência [ \pm afluente]. Escolaridade só não foi significativa para apagamento versus realização de $/ \mathrm{r} /$ em coda.

Para rotacismo, somente a variável linguística posição do /r/ na sílaba apresentou associação significativa. Enquanto isso, as variáveis linguísticas com associação significativa com $/ \mathrm{r} / \mathrm{em}$ ataque foram: contexto fônico precedente [ \pm alto] e [ \pm anterior], contexto fônico seguinte [ \pm alto] e [ \pm anterior] e classe morfológica.

Para ambas as variáveis de $/ \mathrm{r} / \mathrm{em}$ coda, as variáveis linguísticas significativas foram: contexto fônico precedente [ \pm alto] e [ \pm anterior], contexto fônico seguinte [ \pm sonoro], tonicidade e classe morfológica. A variável posição do /r/ na palavra só apresentou associação significativa com apagamento versus realização em /r/ em coda.

Os dados demonstram que as mulheres tendem a favorecer as variantes de prestígio - a não ocorrência de rotacismo, o tepe em ataque e o retroflexo fraco ou apagamento em coda. Porém, dados individuais apontam que nem todos os informantes seguem esse padrão, fato que merece um olhar um pouco mais aprofundado.

Nas faixas etárias mais baixas, por exemplo, o favorecimento das variantes de prestígio é mais generalizado, fato que pode apontar para uma mudança em curso. Enquanto isso, os homens de classe mais alta - exceto o informante da terceira faixa etária - tendem a favorecer essas variantes tanto quanto (ou até mais) do que as mulheres de classe alta.

Nos casos das variantes estigmatizadas de rotacismo e $/ \mathrm{r} /$ em ataque, é interessante notar que as diferenças entre os dados dos informantes são contrastantes. O rotacismo ocorre na grande maioria das vezes na fala dos homens mais velhos, fato que corrobora a hipótese do desaparecimento da variante na comunidade. Quanto ao retroflexo em ataque, dos quatro falantes que mais o produzem, três são homens, sendo um de terceira faixa etária e classe social mais alta, e dois de classe mais baixa e de primeira e segunda faixa etária.

\section{Conclusões}

A partir das análises feitas até o momento, pode-se concluir que a variável sexo/gênero influencia a variação linguística em Piracicaba-SP. A maneira como se dá essa influência, no entanto, não deve ser simplificada. Análises mais qualitativas e individuais parecem apontar para um certo prestígio coberto (TRUDGILL, 1972) das variantes estigmatizadas, além de uma relação complexa dos falantes com essas variantes, que se tornaram símbolo da comunidade.

LABOV, W. The intersection of sex and social class in the course of linguistic change. Language variation and change, Cambridge University Press, v. 2, n. 2, 1990, p. 205-254.

PAIVA, M. C. A variável gênero/sexo. In: MOLLICA, M. C.; BRAGA, M. L. (Orgs.). Introdução à Sociolingüística: o tratamento da variação. São Paulo: Contexto, 2004. p. 33-42.

R CORE TEAM. R: A language and environment for statistical computing. R Foundation for Statistical Computing, Vienna, Austria, 2018. Disponível em: $<$ https://www.R-project.org/>. Acesso em 22 de abr. 2018.

Trudgill, Peter (October 1972). "Sex, Covert Prestige and Linguistic Change in the Urban British English of Norwich". Language in Society. 1 (2): 175-195. 